\title{
Continuity and Change in Premarital Sex in Vietnam
}

\section{BySharon Ghuman, \\ Vu Manh Loi, \\ Vu Tuan Huy and \\ John Knodel \\ Sharon Ghuman is resident fellow at the \\ Population Council, New York. \\ $\mathrm{Vu}$ Manh Loi is deputy head, and Vu \\ Tuan Huy is head, \\ Section of Family \\ Sociology, Institute of \\ Sociology, Vietnam \\ Academy of Social \\ Sciences, Hanoi, \\ Vietnam. John \\ Knodel is professor emeritus, Department \\ of Sociology and the \\ Population Studies \\ Center, University of \\ Michigan, Ann Arbor, MI, USA.}

\begin{abstract}
CONTEXT: Premarital sexual activity is thought to be rising in Vietnam. However, there is little evidence documenting such an increase, and it is unknown whether levels of premarital sex differ between northern and southern Vietnam and whether premarital sex occurs primarily with a future spouse.
\end{abstract}

METHODS: Surveys conducted in northern Vietnam (Red River Delta) and southern Vietnam (Ho Chi Minh City and surrounding environs) in 2003-2004 among individuals married during one of three important periods in Vietnamese history (1963-1971, 1977-1985 or 1992-2000) were used to assess trends and regional differences in the prevalence and context of premarital sex.

RESULTS: In both regional samples, 31\% of men who married in 1992-2000 reported having had premarital sex. The proportion was much lower among women ( $8 \%$ in the South, $12 \%$ in the North). The prevalence of premarital sex rose markedly across cohorts in the North but only modestly in the South. Relatively few men had premarital sex with someone other than a future spouse (3-23\%). The proportion of the rise in the prevalence of premarital sex that was due to sex exclusively with a future spouse was greater in the North (42\%) than in the South (25\%).

CONCLUSIONS: These results suggest that premarital sex is becoming more common in Vietnam but is still not widespread. Better information about the sexual networks of men in the general population and their contacts with highrisk groups (e.g., commercial sex workers) is needed to ascertain the likelihood that HIV/AIDS will spread to the general population.

International Family Planning Perspectives, 2006, 32(4):166-174

As the AIDS epidemic continues to spread across Asia, there is growing concern that the prevalence of risky sexual activity among young people may be rising. Such concerns are prominent in Vietnam, where the market reforms that were initiated during the late 1980s (doi moi) have introduced a variety of new media from abroad, and encouraged the growth of consumer culture and migration to urban areas among younger individuals. ${ }^{1}$ Although confirmatory data are lacking, these trends are thought to be contributing to increases in sexual permissiveness, STIs, unintended pregnancy and abortion among adolescents. ${ }^{2}$ The number of HIV infections in Vietnam has increased rapidly since the early 1990s. ${ }^{3}$

Systematic information on any changes that have occurred in the prevalence and context of premarital sexual activity in Vietnam would help provide an understanding of the relationship among social and economic change, premarital sexual behavior and the transmission of STIs, including HIV/AIDS. Not only is there a lack of reliable evidence that the prevalence of premarital sex is rising in Vietnam, but there is little information regarding whether premarital sex occurs primarily within monogamous relationships-in particular, with the person an individual intends to marry-or with multiple partners (including, perhaps, commercial sex workers). This is a significant gap in our knowledge, because the extent to which individuals have casual sex with multiple partners has clear relevance for the spread of HIV.

In the current study, we examine trends in premarital sexual activity using surveys conducted in 2003 and 2004 among married men and women in northern Vietnam (the Red River Delta region) and southern Vietnam (Ho Chi Minh City and surrounding provinces). The data were collected from individuals who married during one of three important periods in Vietnamese history: the first two-thirds of the war with the United States (1963-1971); a period of economic crisis after the reunification of South Vietnam and North Vietnam (1977-1985); and a time of economic liberalization and greater openness to the West (19922000). The focus on these three periods affords a unique opportunity to assess changes in premarital sexual behavior across three cohorts that have experienced significant social and economic upheaval. We examined levels of premarital sex, sexual initiation by type of partner and the extent to which premarital sex was restricted to future spouses or involved other individuals whom respondents did not marry. To our knowledge, this is the first study to examine trends in premarital sex using data that span both northern and southern Vietnam and that encompass the premarital sexual experiences of both individuals who married prior to the doi moi period and those who married when it was well under way. 


\section{BACKGROUND}

\section{Premarital Sex in Vietnam}

Current knowledge about premarital sex in Vietnam is largely based on studies of convenience samples of youth or of women interviewed at abortion clinics in and near Hanoi. ${ }^{4}$ These studies suggest that younger individuals are more likely than their elders to view sex before marriage (particularly with a future spouse) as acceptable. We know of two studies that provide information about premarital sex collected from large representative samples. The first study, which was based on a survey of adolescents and young adults from six diverse Vietnamese provinces (including Ho Chi Minh City), estimated that by age 22, 29\% of unmarried men and $16 \%$ of unmarried women have had sex. ${ }^{5}$ As the authors noted, the proportion of women in their sample who were sexually active by age 20 is much lower than the proportions in the Philippines, Thailand and all 32 countries in Latin America and Sub-Saharan Africa in which demographic and health surveys have been conducted. The second study, the nationally representative Survey Assessment of Vietnamese Youth, found that among never-married respondents aged $22-25$, about $33 \%$ of men and $4 \%$ of women in urban areas, and $26 \%$ of men and $3 \%$ of women in rural areas, reported ever having had premarital sex. ${ }^{6}$

It is not known how well these estimates approximate the true prevalence of premarital sex in Vietnam. The collection of accurate data, especially in face-to-face interviews, on sensitive activities such as sex poses a number of challenges. ${ }^{7}$ In some U.S. surveys-even those that were selfadministered, a format that mitigates the potential embarrassment of a face-to-face interview-many participants did not answer questions pertaining to sexual behavior. ${ }^{8}$ Premarital sex, particularly if it occurs outside of a stable union that will lead to marriage, is considered socially taboo in Vietnam; ${ }^{9}$ therefore, in face-to-face interviews, respondents may be reluctant to report such activity. Women may be more reticent than men about disclosing their sexual behavior in an interview: In prior studies in Vietnam, unmarried men were three ${ }^{10}$ and seven ${ }^{11}$ times as likely as women to report having had premarital sex. This reporting bias is likely to be smaller in studies of married people, because married individuals (especially women) may feel more comfortable than their unmarried peers about reporting sex that occurred before marriage. For example, in the study of adolescents and young adults from six Vietnamese provinces, about half of married women reported having had premarital sex, compared with only $6 \%$ of unmarried women. ${ }^{12}$

\section{AIDS}

The AIDS epidemic has spread to all provinces in Vietnam, although cases are concentrated in urban centers around Hanoi, Ho Chi Minh City and the northern areas that border China. ${ }^{13}$ The number of cases is especially high among intravenous drug users and men aged 20-39, and it is higher in the South than in the North. HIV has yet to spread to the general population: The infection rate among pregnant women is less than $1 \%$. However, there is concern that the epidemic will spread beyond core high-risk groups if men who visit female sex workers or use intravenous drugs transmit the infection to their wives or other female partners through unprotected sex. ${ }^{14}$ This pattern of transmission has been the primary means by which HIV has spread in Thailand and Cambodia, and studies of drug users in northern Vietnam suggest that the majority of these individuals are sexually active and engaged in needle sharing, making this scenario plausible for Vietnam as well. ${ }^{15}$ Some studies suggest that the prevalence of HIV and other STIs is rising among commercial sex workers, who are often inconsistent in their condom use with clients and who frequently use injection drugs. ${ }^{16}$ These observations point to the need for further information about the levels and patterns of premarital sexual activity (particularly with sex workers and other casual partners) among men in Vietnam, because such activity places these men's current or future wives at risk of contracting HIV and other STIs.

\section{Regional Differences}

Northern and southern Vietnam differ in their economic, social and political histories, and these differences are likely to have important implications for premarital sexual behavior. The Democratic Republic of Vietnam that was formed in the northern part of the country in 1945 had a strong influence ${ }^{*}$ on family life in northern Vietnam, ${ }^{17}$ but until the reunification period that influence did not extend to the South, where the French occupation (1875-1954) and the American presence that began in the mid-1960s exposed the population (particularly in urban areas) to Western ideas. ${ }^{18}$ Private enterprise and commerce have a longer history in the South than in the North, and they have endured during the reunification period. In addition, compared to their counterparts in the North, residents of southern Vietnam have had access to a wider array of information and perspectives from newspapers, journals, magazines and television. ${ }^{19}$

During the war with the United States, commercial sex outlets (many of which often catered to Americans) were more common in the South (particularly in Ho Chi Minh City) than in the North, although many of these outlets were closed by the government following reunification. Reliable estimates of the distribution of sex workers across Vietnam are difficult to obtain; however, commercial sex outlets are thought to be making a resurgence, and by some accounts there were 50,000-70,000 female sex workers in Ho Chi Minh City in the mid-1990s. ${ }^{20}$

Accordingly, observers of Vietnamese society suggest that social mores and lifestyles are less conservative in the southern part of the country than in the North. ${ }^{21}$ However, there is little credible evidence to date on how social context relates to premarital sex in Vietnam.

*In northern Vietnam, laws designed to discourage such practices as arranged marriage, polygamy, child marriage and elaborate marriage ceremonies were ultimately successful in changing the nature of mate selection and marriage practices. 


\begin{tabular}{|c|c|c|c|c|c|c|c|c|c|c|c|c|}
\hline Characteristic & \multicolumn{3}{|l|}{ Men } & \multicolumn{3}{|l|}{ Women } & \multicolumn{3}{|l|}{ Men } & \multicolumn{3}{|l|}{ Women } \\
\hline \multicolumn{13}{|c|}{$\begin{array}{l}\text { \% DISTRIBUTIONS } \\
\text { Grades completed in school\# }\end{array}$} \\
\hline $1-5$ & 2.8 & 1.4 & 1.9 & 8.9 & 1.4 & 3.7 & 40.8 & 19.2 & 14.4 & 61.5 & 41.2 & 26.3 \\
\hline $6-9$ & 46.0 & 49.1 & 37.2 & 63.9 & 55.8 & 54.0 & 25.2 & 40.4 & 40.3 & 20.2 & 28.9 & 45.5 \\
\hline $10-12$ & 35.6 & 39.2 & 47.4 & 15.0 & 33.5 & 32.1 & 24.8 & 30.3 & 33.3 & 14.0 & 25.6 & 23.4 \\
\hline$\geq 12$ & 15.6 & 10.3 & 13.5 & 12.2 & 9.3 & 10.2 & 9.2 & 10.1 & 12.0 & 4.3 & 4.3 & 4.8 \\
\hline \multicolumn{13}{|l|}{ Wealth } \\
\hline <sample median & 89.8 & 87.9 & 94.4 & 87.8 & 89.7 & 89.8 & 57.3 & 56.4 & 66.0 & 57.3 & 64.8 & 66.7 \\
\hline zsample median & 10.2 & 12.1 & 5.6 & 12.2 & 10.3 & 10.2 & 42.7 & 43.6 & 34.0 & 42.7 & 35.2 & 33.3 \\
\hline \multicolumn{13}{|l|}{ Urban } \\
\hline$<$ sample median & 31.1 & 31.8 & 37.4 & 30.2 & 25.0 & 26.2 & 13.6 & 21.8 & 21.0 & 17.5 & 13.2 & 17.3 \\
\hline zsample median & 68.9 & 68.2 & 62.6 & 69.8 & 75.0 & 73.8 & 86.4 & 78.2 & 79.0 & 82.5 & 86.8 & 82.7 \\
\hline Total & 100.0 & 100.0 & 100.0 & 100.0 & 100.0 & 100.0 & 100.0 & 100.0 & 100.0 & 100.0 & 100.0 & 100.0 \\
\hline
\end{tabular}

\section{DATA AND METHODS}

The data used in this analysis were collected by the Institute of Sociology in Hanoi as part of the Vietnam Surveys of Family Change. The first survey was conducted in March-April 2003 in seven provinces (including Hanoi) in northern Vietnam's Red River Delta. The second survey, which used an identical questionnaire, was conducted in 2004 in Ho Chi Minh City and six contiguous provinces spanning substantial parts of the Southeast and Mekong River Delta regions. For convenience, we refer to the Red River Delta sample as the "North" and the Ho Chi Minh City and environs sample as the "South."

Each survey was administered to 1,296 married individuals, split equally between men and women, rural and urban residents, and the three marriage cohorts described above; thus, the total sample comprised 2,592 respondents and $12(2 \times 2 \times 3)$ different gender-residence-cohort combinations. There were no age restrictions on participation; however, to minimize the inclusion of childless marriages, which were of less relevance to the main research aims of the survey, the sample was limited to marriages in which female respondents (or the wives of male respondents) were younger than 40 at the time of marriage. The surveys were conducted by 67 interviewers ( 30 women, 37 men), all of whom were researchers at the Institute of Sociology or lecturers at either the Department of Sociology at Hanoi University or the Center of Sociology at Ho Chi Minh Political Academy.

Behavior during the early years of marriage was an important focus of the survey and influenced the selection of the three marriage cohorts. The range of marriage dates for the war cohort (1963-1971) thus ends a few years before North Vietnam's victory to ensure that respondents' early marital experiences occurred during the time of conflict. The middle cohort (1977-1985) was chosen to capture new marriages during a period when postreunification economic distress and stagnation were at their height. ${ }^{22}$ And although the official start of the doi moi period is considered to be 1986, many reforms did not begin in earnest until the early $1990 \mathrm{~s} ;{ }^{23}$ as a result, the starting date for the third cohort (1992-2000) was chosen to ensure that sufficient time had elapsed for the impact of economic reforms on family and individual behavior to be observed.

For each survey, respondents were drawn from nine urban districts or towns and nine rural districts, all of which were chosen randomly. Within each district, three wards (urban) or communes (rural) were selected, and in each ward or commune, two administrative residential groupings (urban) or villages (rural) were chosen. Twelve households were randomly selected within each village or residential grouping using a preset interval determined by the number of dwellings within the sample site and the estimated number of households that needed to be visited to obtain the desired number of interviews in each category (i.e., two married men and two married women from each marriage cohort who met the other eligibility criteria). A member of each household was asked a short set of screening questions to determine if the household contained an eligible respondent. In any given household, either the husband or the wife was interviewed. Screening at the sample 
site continued until the required number of interviews of each type was reached. Each regional sample was designed to be representative and self-weighting within each of the 12 categories. Response rates were $80 \%$ in the North and $73 \%$ in the South. In most cases, nonresponse was due to the eligible participant not being at home at the time of contact or recontact; refusal to be interviewed accounted for fewer than a third of nonresponses.

Because of the sampling design, survey respondents differ from the general population of Vietnam. Almost threefourths of Vietnam's population is rural; ${ }^{24}$ the study sample is half rural. Very young married persons are disproportionately omitted from the study because the most recent marriage cohort excluded persons married for fewer than 3-4 years; if the prevalence of premarital sex among adolescents and individuals married for very short durations is increasing rapidly, then our analysis is likely to understate the occurrence of premarital sex. Given the many unique features and limitations of the sample, we do not attempt to weight the results to make them representative of the Vietnamese population.

The survey contained three items that pertained to premarital sex. First, respondents were asked whether the first time they had sexual intercourse with their spouse was before or after they were married. Respondents were then asked whether they had had sex with someone other than their spouse before marriage. A comparison of these two items provides information on the proportion of respondents who had had sex before marriage with anyone, with their spouse, with someone other than their spouse, or with both their spouse and someone else. Finally, respondents were asked whether their first sex partner was their spouse, a boyfriend or girlfriend, a casual acquaintance or a commercial sex worker.

We omitted from the analysis the 74 respondents (3\% of the sample) who had been married more than once. Many of these respondents had had premarital sex with their previous spouse, thus confounding the answers to the survey questions regarding premarital sex, because the survey did not ask about sex before the first marriage. In addition, 20 respondents (12 men and eight women) did not answer the question on whether the first time they had sex with their spouse was before marriage; 19 of these respondents went on to report that they had not had sex with anyone else before marriage, and 10 did not answer the question on the first person with whom they had sex (the other 10 respondents named their spouse). Because we cannot infer whether these 20 people had premarital sex, they are not included in this analysis. Thus, the final sample included 2,498 respondents.

The main focus of the analysis is descriptive. Because rates of premarital sex were much lower among women than among men, we have focused some of our analyses on men, or on men in recent marriage cohorts, who account for much of the occurrence of premarital sex. We conclude by calculating the mean predicted probabilities* that men had premarital sex (with either their future spouse or someone
FIGURE 1. Percentage of respondents who reported having had premarital sex, by gender, region and marriage cohort

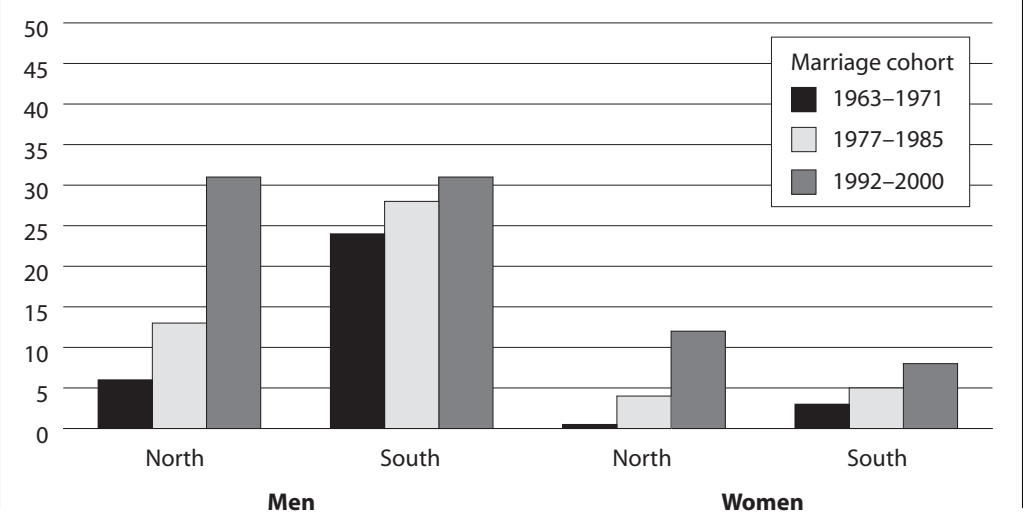

else) and that women had premarital sex with their future spouse; these probabilities are presented separately by region and by characteristics such as educational attainment, wealth, urban or rural residence, and marriage cohort. ${ }^{25}$ We include age at marriage as a continuous variable in all of the models to control for differential exposure to premarital sex across the three marriage cohorts.

\section{RESULTS}

\section{Sample Characteristics}

Table 1 shows the distribution of selected characteristics of the sample, by region, gender and marriage cohort. Between the earliest and most recent cohorts, the respondents' average age at marriage rose modestly in the North, but only among men; in the southern sample, the mean age at marriage rose by about three years among both men and women. The northern sample has more schooling than the southern sample; in the most recent cohort, for example, the proportion of respondents who had had 10 or more years of schooling is greater in the North than in the South for both men ( $61 \%$ vs. $45 \%$ ) and women (42\% vs. $28 \%$ ). As per the study design, about half of respondents for each gender-marriage cohort combination lived in rural areas. In both rural and urban areas, respondents who lived in the South were more likely than their northern counterparts to score above the sample median on an index of wealth,$^{\dagger}$ suggesting higher socioeconomic status in the South than in the North.

*These predicted probabilities are calculated using a logistic regression in which $\operatorname{Pr}(y=1)=e^{(x i B)} / 1+e^{(x i B)}, y$ is a binary indicator for whether an individual had premarital sex, $B$ represents the relevant estimated coefficient for each of the variables from the right-hand side of the model, and all the individuals $i$ take on the value for the category for which the predicted values are calculated while the rest of the variables are left as in the data. These predicted probabilities are then averaged across the individuals in the analytic sample.

†To categorize respondents' wealth, we used an index that is based on the following assets and housing characteristics: ownership of a color television, DVD player, radio, radio/cassette player, motorcycle, telephone, cell phone, car, refrigerator, air conditioner and washing machine; residence in a household with a cupboard, gas cooker, hot water heater, flush toilet and indoor bathroom; and ownership of a permanent structure in fair or good condition (as opposed to a shack, hut or temporary structure). 


\begin{tabular}{|c|c|c|c|c|c|c|}
\hline \multirow[t]{2}{*}{ Respondents } & \multicolumn{3}{|l|}{ North } & \multicolumn{3}{|l|}{ South } \\
\hline & $\begin{array}{l}1963- \\
1971\end{array}$ & $\begin{array}{l}1977- \\
1985\end{array}$ & $\begin{array}{l}1992- \\
2000\end{array}$ & $\begin{array}{l}1963- \\
1971\end{array}$ & $\begin{array}{l}1977- \\
1985\end{array}$ & $\begin{array}{l}1992- \\
2000\end{array}$ \\
\hline All men & $(\mathrm{N}=210)$ & $(\mathrm{N}=214)$ & $(\mathrm{N}=213)$ & $(\mathrm{N}=204)$ & $(\mathrm{N}=195)$ & $(\mathrm{N}=199)$ \\
\hline Spouset & 3.3 & 11.7 & 22.1 & 12.7 & 11.3 & 15.1 \\
\hline Nonspouset & 2.9 & 2.8 & 16.9 & 16.7 & 23.1 & 22.1 \\
\hline All women & $(\mathrm{N}=211)$ & $(\mathrm{N}=215)$ & $(\mathrm{N}=213)$ & $(\mathrm{N}=206)$ & $(\mathrm{N}=210)$ & $(\mathrm{N}=208)$ \\
\hline Spouset & 0.5 & 3.7 & 11.7 & 2.4 & 4.8 & 8.2 \\
\hline Nonspouset & 0.0 & 0.9 & 0.5 & 1.5 & 0.5 & 1.4 \\
\hline $\begin{array}{l}\text { Men who had } \\
\text { premarital sex }\end{array}$ & $(\mathrm{N}=13)$ & $(\mathrm{N}=27)$ & $(\mathrm{N}=65)$ & $(\mathrm{N}=49)$ & $(\mathrm{N}=54)$ & $(\mathrm{N}=62)$ \\
\hline Spouse onlył & 53.9 & 77.8 & 44.6 & 30.6 & 16.7 & 29.0 \\
\hline $\begin{array}{l}\text { Nonspouse only } \neq \\
\text { Both spouse and }\end{array}$ & 46.2 & 7.4 & 27.7 & 47.0 & 59.3 & 51.6 \\
\hline nonspouse $\neq$ & 0.0 & 14.8 & 27.7 & 22.5 & 24.1 & 19.4 \\
\hline Total & 100.0 & 100.0 & 100.0 & 100.0 & 100.0 & 100.0 \\
\hline
\end{tabular}

tRespondents who had premarital sex both with their spouse and with a nonspouse are included in both categories. $\neq$ Categories are mutually exclusive. Note: Percentages may not total 100 because of rounding.

\section{Premarital Sex}

Respondents in the 1992-2000 cohort were more likely than members of the earlier cohorts to report having had premarital sex (Figure 1, page 169). Among men in the North, for example, $31 \%$ of those in the most recent cohort said they had had premarital sex, compared with $6 \%$ and $13 \%$ in the two earlier cohorts. Levels of premarital sex also rose in the South, but much more modestly, from $24 \%$ to $31 \%$. Although premarital sex was more common in the South than in the North among men in the 1963-1971 and 1977-1985 cohorts, the recent increase in the North led to convergence between the two regions.

In both regions and in all three marriage cohorts, women were considerably less likely than men to report having had premarital sex. Between the earliest and most recent cohorts, the prevalence of premarital sex among female respondents increased from about $1 \%$ to $12 \%$ in the North and from $3 \%$ to $8 \%$ in the South.

\section{Premarital Sex Partners}

The top half of Table 2 shows the proportion of respondents who had premarital sex with a future spouse and the proportion who had premarital sex with someone they did not

\begin{tabular}{|c|c|c|c|c|c|c|}
\hline \multirow[t]{2}{*}{ Partner } & \multicolumn{3}{|l|}{ North } & \multicolumn{3}{|l|}{ South } \\
\hline & $\begin{array}{l}1963- \\
1971 \\
(N=210)\end{array}$ & $\begin{array}{l}1977- \\
1985 \\
(N=214)\end{array}$ & $\begin{array}{l}1992- \\
2000 \\
(N=213)\end{array}$ & $\begin{array}{l}1963- \\
1971 \\
(N=203)\end{array}$ & $\begin{array}{l}1977- \\
1985 \\
(\mathrm{~N}=193)\end{array}$ & $\begin{array}{l}1992- \\
2000 \\
(N=196)\end{array}$ \\
\hline Spouse & 97.1 & 97.2 & 84.0 & 83.7 & 77.2 & 79.1 \\
\hline Girlfriend & 1.9 & 1.4 & 13.2 & 9.4 & 16.1 & 16.8 \\
\hline Casual acquaintance & 1.0 & 0.9 & 0.5 & 2.5 & 3.6 & 1.0 \\
\hline Commercial sex worker & 0.0 & 0.5 & 2.4 & 4.4 & 3.1 & 3.1 \\
\hline Total & 100.0 & 100.0 & 100.0 & 100.0 & 100.0 & 100.0 \\
\hline
\end{tabular}

marry. Among men in the North, the prevalence of premarital sex with one's spouse increased substantially, from 3\% in the earliest cohort to $22 \%$ in the doi moi cohort. A similar increase, from $3 \%$ to $17 \%$, occurred for premarital sex with someone other than a future spouse. Among men in the South, the changes across cohorts were less pronounced; rates varied between $11 \%$ and $15 \%$ for sex with a future spouse and between $17 \%$ and $23 \%$ for sex with someone other than a future spouse. In both the North and the South, women in the 1992-2000 cohort were about half as likely as men in that cohort to report that they had had sex with their future spouse before marriage; the differences were even greater in earlier cohorts. Very few women (0-2\%) reported having had sex with someone other than their future spouse, regardless of cohort or region.

The lower half of Table 2 examines the distribution of premarital sex partners (using mutually exclusive categories) among men who had sex before marriage. Given the small number of cases, particularly in the first two periods, it is difficult to reliably assess patterns across cohorts. In the 1992-2000 cohort, the overall level of premarital sex reported by men in the North was similar to that of men in the South, but there were important regional difference in the type of premarital sex partners. In the North, 55\% of men in the most recent cohort who had premarital sex did so with someone other than their future spouse; this includes men who had premarital sex exclusively with a nonspouse as well as those who had sex with both their spouse and a nonspouse. In the South, $71 \%$ of men in this cohort who engaged in any sexual intercourse before marriage did so with someone other than their current spouse. Among men in the North, about $42 \%$ of the increase in the prevalence of premarital sex between the earliest and most recent cohorts is due to sex only with a spouse, and the remaining $58 \%$ is due to sex that involved someone other than a future spouse (irrespective of whether they also had sex with their spouse; not shown). In the South, only 25\% of the increase is due to sex only with a future wife, and $75 \%$ is attributable to premarital sex that did not involve a future spouse. These findings indicate that men who had premarital sex exclusively with their future wife account for a significant proportion of the increase in premarital sex in the North but not in the South.

\section{First Partner}

In the North, the proportion of men whose first sexual partner was their future spouse declined, from near universality in the first two cohorts to $84 \%$ in the most recent cohort (Table 3). The remaining men in the most recent cohort reported that they first had sexual intercourse with a girlfriend (13\%) or with a casual acquaintance or commercial sex worker (3\%). The proportion of men who said that their first act of intercourse occurred with their spouse declined in the South as well (although to a lesser extent than in the North), while the proportion who first had sex with a girlfriend increased from $9 \%$ to $17 \%$. In the two earlier cohorts, men in the South were far more likely than those in the 
North to report that a girlfriend, casual acquaintance or sex worker was their first sex partner. Overall, the distribution of men by first sex partner is converging between the two regions, primarily due to the recent increases in the proportion of men in the North who initiated sex with a girlfriend rather than with a future spouse. Virtually all women reported that their first sexual intercourse was with their spouse (not shown).

Of the 77 men in the most recent marriage cohort who had premarital sex with someone other than their future spouse, the vast majority had sex for the first time with someone they did not eventually marry. Only $2 \%$ of men in the South and $8 \%$ of men in the North initiated sex with their future spouse and subsequently had premarital sex with someone else (not shown). In both regions, $78 \%$ of men who had premarital sex with someone other than their future spouse did so for the first time with a girlfriend; the remainder initiated sex with a commercial sex worker (15\% in the South, $14 \%$ in the North) or a casual acquaintance ( $5 \%$ in the South, none in the North).

\section{Probabilities for Premarital Sex}

Table 4 shows the mean predicted probability that a male respondent had premarital sex and that a female respondent had premarital sex with her current spouse, according to region and respondent characteristics. In both the North and South, respondents' probability of premarital sex did not differ by education level or wealth. In the North, urban residents had a higher probability of premarital sex than did rural residents, among both men (25\% vs. 9\%) and women ( $9 \%$ vs. 3\%). In the South, however, the probability of premarital sex was similar for urban and rural residents. Finally, in the North, men and women in the two most recent marriage cohorts were more likely than members of the 1963-1971 cohort to have had premarital sex; in the South, women in the 1992-2000 cohort had a higher probability of premarital sex than their 1963-1971 counterparts, but men's probability of premarital sex did not differ by marriage cohort.

\section{DISCUSSION}

Our data indicate that premarital sex is becoming increasingly common in Vietnam, especially in the Red River Delta region, where the level of premarital sex among men married in 1992-2000 was on par with the level observed in the South. There is a strong and consistent relationship between premarital sex and belonging to a recent marriage cohort among men in the North, and between premarital sex with a future spouse and belonging to a recent marriage cohort among women in both the North and South. These findings support the hypothesis that in recent years, important socioeconomic, cultural and attitudinal changes, perhaps arising in part from economic liberalization, have contributed to rising sexual activity before marriage.

Although our data are not representative of Vietnam as a whole or of any of its regions, the findings regarding premarital sex are broadly reflective of the current situation TABLE 4. Mean predicted probability of premarital sex, by region and gender of
respondent, according to selected characteristics

\begin{tabular}{|c|c|c|c|c|}
\hline \multirow[t]{2}{*}{ Characteristic } & \multicolumn{2}{|l|}{ North } & \multicolumn{2}{|l|}{ South } \\
\hline & $\begin{array}{l}\text { Ment } \\
(\mathrm{N}=637)\end{array}$ & $\begin{array}{l}\text { Women } \neq \\
(\mathrm{N}=639)\end{array}$ & $\begin{array}{l}\text { Ment } \\
(\mathrm{N}=593)\end{array}$ & $\begin{array}{l}\text { Women } \neq \\
(\mathrm{N}=622)\end{array}$ \\
\hline \multicolumn{5}{|c|}{ Grades completed in school§ } \\
\hline 1-9(ref) & 14.8 & 4.7 & 26.3 & 4.6 \\
\hline$\geq 10$ & 17.6 & 6.1 & 30.1 & 6.8 \\
\hline \multicolumn{5}{|l|}{ Residence } \\
\hline Urban (ref) & 24.5 & 8.7 & 26.3 & 5.4 \\
\hline Rural & $8.9^{*}$ & $3.0^{*}$ & 29.3 & 4.9 \\
\hline \multicolumn{5}{|c|}{ Wealth index quartile } \\
\hline Lowest (ref) & 17.8 & 6.5 & 31.0 & 6.1 \\
\hline Second & 16.8 & 3.1 & 25.8 & 3.9 \\
\hline Third & 17.4 & 5.1 & 26.8 & 3.6 \\
\hline Highest & 14.1 & 5.8 & 29.2 & 7.2 \\
\hline \multicolumn{5}{|l|}{ Marriage cohort } \\
\hline 1963-1971(ref) & 6.2 & 0.5 & 24.7 & 2.1 \\
\hline 1977-1985 & $12.7^{*}$ & $4.1^{*}$ & 28.5 & 4.8 \\
\hline 1992-2000 & $30.2^{*}$ & $10.9^{*}$ & 30.3 & $9.6^{*}$ \\
\hline
\end{tabular}

*Differs significantly from reference group at $\mathrm{p}<.05$. †Probability of having had premarital sex with any partner. \#Probability of having had premarital sex with current spouse. §Respondents who were illiterate were categorized as having completed 1-5 grades. Notes: ref=reference group. All probabilities control for age at marriage.

in Vietnam. In the Survey Assessment of Vietnamese Youth, $37 \%$ of married men aged $22-25$ and $13 \%$ of married women in that age-group reported having had sex before marriage. ${ }^{26 *}$ The findings from that survey are thus fairly consistent with the levels of premarital sex reported by members of our 1992-2000 marriage cohort (31\% for men in both regions and $8 \%$ and $12 \%$, respectively, for women in the North and South). Other basic characteristics of our northern and southern samples, such as the higher levels of educational attainment and lower levels of wealth in the North, are also consistent with recent and representative data from comparable areas. ${ }^{27}$

Although men in the North and those in the South were similar in terms of their propensity to report premarital sex, there are important regional differences in the characteristics of premarital sexual behavior. Men in the North were more likely than those in the South to have had premarital sex only with their future wife, whereas men in the South more commonly had had premarital sex with someone other than their spouse. Thus, among men who had premarital sex, those in the South were more likely than their counterparts in the North to have placed their spouse at some level of risk for HIV/AIDS or other STIs. However, even in the South, the proportion of men who had premarital sex with someone other than their future spouse was relatively low (17-23\%, compared with $3-17 \%$ in the North).

Having sex exclusively within a relationship that leads to marriage (as opposed to having premarital sex with other

*We compare our results with those for 22-25-year-olds in the Survey Assessment of Vietnamese Youth, rather than those for 15-21-year-olds, because rates of premarital sex in the younger age-group may be inflated by the inclusion of individuals who married due to a pregnancy resulting from premarital sex. 
individuals) has made a greater contribution to the increase in premarital sexual activity in the North than in the South. The differences in sociopolitical history between the two regions likely contribute to the more conservative nature of premarital sex in the North. Among men in the recent marriage cohort who had had sex before marriage with someone other than their spouse, most initiated intercourse with a girlfriend; about $15 \%$ of this very small group of respondents reported having had their first sexual intercourse with a sex worker.

The high response rate in our study does not guarantee accurate responses to survey items; instead of declining to answer questions that they considered embarrassing, some respondents may have falsely denied having had premarital sex. The gender differences in the reported levels of premarital sexual activity underscore the challenge of measuring sexual behavior in interviewer-administered surveys. On average, the percentages of male and female respondents who had had sex with their spouse prior to marriage should be similar. However, in the most recent marriage cohort, women were about half as likely as men to report that they had had sex with their future spouse before marriage.* This gender difference suggests that women considerably underreported the degree to which they had sex with their spouse before marriage (or that men overreported premarital sex with their spouse). Because only one person was surveyed in each household, we cannot directly compare husbands' and wives' reports on this item.

A similar phenomenon may contribute to the differences in rates of premarital sex across marriage cohorts. If respondents from the earlier cohorts were more conservative than those in the 1992-2000 cohort about discussing sex with an interviewer, they may have been less likely to acknowledge having had premarital sex, resulting in underreporting in these cohorts. However, it is also possible that because their premarital sexual experiences occurred in the more distant past, older respondents felt less uncomfortable about revealing such experiences than did younger respondents who married more recently.

Although premarital sex is becoming more common in Vietnam, our results show that it remains far from widespread. Even in the most recent marriage cohort, about 70\% of men and $90 \%$ of women said that they had not had premarital sex. Of those who reported having had sex before marriage, a substantial proportion-particularly among women and among men in the North-had premarital sex only in a committed relationship with a future spouse. In both the North and the South, the vast majority of men who had sex before marriage initiated this activity within a relatively stable relationship (i.e., with either a girlfriend or a

*These gender differences were also observed in the Survey Assessment of Vietnamese Youth, in which married men aged 22-25 were about twice as likely as women in the same age-group to report that they had had sex with their spouse before marriage ( $28 \%$ vs. $13 \%$ ). If men aged $22-25$ are compared with women 22 or younger to account for the fact that husbands tend to be older than their wives, men are still about 1.5 times as likely as women to report having had sex with their spouse before marriage $(28 \%$ vs. $18 \%)$. future spouse) rather than with higher-risk individuals such as sex workers or casual acquaintances. It is possible that participants underreported their patronage of commercial sex workers, given that such behavior is widely denounced by the government as a "social evil."

The question of whether, and how, premarital sexual behavior in Vietnam will continue to evolve as the country undergoes further economic and social change and the North and South become increasingly integrated will remain an important area of inquiry. Studies that measure premarital sexual behavior using alternate interview modes that confer more privacy to respondents than do face-to-face interviews may be a useful way to obtain better information about sexual behavior in Vietnam, particularly related to high-risk partnerships among men. For example, in a pilot study near Hanoi among individuals aged 15-24, the proportion of unmarried men who reported having had sex with a commercial sex worker was substantially higher with audio computer-assisted self-interviews than with self-administered questionnaires ( $8 \%$ vs. $1 \%$ ). ${ }^{28}$ Intensive interventions to assist high-risk groups (e.g., injection drug users, sex workers) in reducing their risk of contracting and spreading the virus are important; ${ }^{29}$ in addition, research is needed that describes in more depth the sexual networks of high-risk groups and of men in the general population in settings where HIV is spreading quickly, ${ }^{30}$ so that the potential for infection of low-risk groups can be better assessed.

\section{REFERENCES}

1. Dang A, Goldstein S and McNally J, Internal migration and development in Vietnam, International Migration Review, 1997, 31(2):312-337; and Marr DG, Education, research, and information circulation in contemporary Vietnam, in: Turley WS and Selden M, eds., Reinventing Vietnamese Socialism: Doi Moi in Comparative Perspective, Boulder, CO, USA: Westview Press, 1993.

2. Haub C and Phuong TTH, Adolescents and Youth in Vietnam, Hanoi, Vietnam, and Washington, DC: Committee for Population, Family and Children of Vietnam and Population Reference Bureau, 2003; Khuat TH, Adolescent and Youth Reproductive Health in Vietnam: Status, Issues, Policies and Programs, Washington, DC: Futures Group International, 2003; and Pham NHT, Vietnam's urban sex culture: is it fueling the HIV/AIDS epidemic? Pacific News, July/Aug. 2004, pp. 6-9.

3. Nguyen TH, Nguyen TL and Trinh QH, HIV/AIDS epidemics in Vietnam: evolution and responses, AIDS Education and Prevention, 2004, 16(Suppl. A):137-154; and Vu MQ et al., HIV in Vietnam: the evolving epidemic and the prevention response, 1996 through 1999, Journal of Acquired Immune Deficiency Syndromes, 2000, 25(4):360-369.

4. Belanger D and Khuat TH, Young single women using abortion in Hanoi, Vietnam, Asia-Pacific Population Journal, 1998, 13(2):3-26; Belanger D and Khuat TH, Single women's experiences of sexual relationships and abortion in Hanoi, Vietnam, Reproductive Health Matters, 1999, No. 14, pp.71-82; Gammeltoft T, The irony of sexual agency: premarital sex in urban northern Vietnam, in: Werner J and Belanger D, eds., Gender, Household, State: Doi Moi in Vietnam, Ithaca, NY, USA: Cornell University Press, 2002; Gammeltoft T, Being special for somebody: urban sexualities in contemporary Vietnam, Asian Journal of Social Science, 2003, 30(3):476-492; Long LD et al., The Doi Moi Generation: Coming of Age in Vietnam Today, Hanoi, Vietnam: Population Council, 2000; and Pham NHT, 2004, op. cit. (see reference 2).

5. Mensch BS, Clark WH and Anh DN, Adolescents in Vietnam: looking beyond reproductive health, Studies in Family Planning, 2003, 34(4):249-262.

6. Vietnam Ministry of Health et al., Survey Assessment of Vietnamese Youth, Hanoi, Vietnam: Vietnam Ministry of Health, 2005, p. 40, Graph 12. 
7. Dare OO and Cleland JG, Reliability and validity of survey data on sexual behaviour, Health Transition Review, 1994, 4(Suppl.):93-110; Fenton KA et al., Measuring sexual behaviour: methodological challenges in survey research, Sexually Transmitted Infections, 2001, 77(2):84-92; and Turner CF, Miller HG and Rogers SM, Survey measurement of sexual behavior: problems and progress, in: Bancroft J, ed., Researching Sexual Behavior: Methodological Issues, Bloomington, IN, USA: Indiana University Press, 1997.

8. Call V, Sprecher S and Schwartz P, The incidence and frequency of marital sex in a national sample, Journal of Marriage and the Family, 1995, 57(3):639-652; and Turner CF, Miller HG and Rogers SM, 1997, op. cit. (see reference 7 ).

9. Gammeltoft T, 2002, op. cit. (see reference 4); and Gammeltoft T, 2003, op. cit. (see reference 4).

10. Mensch BS, Clark WH and Anh DN, 2003, op. cit. (see reference 5).

11. Vietnam Ministry of Health et al., 2005, op. cit. (see reference 6).

12. Mensch BS, Clark WH and Anh DN, 2003, op. cit. (see reference 5).

13. Hammett TM et al., Correlates of HIV status among injection drug users in a border region of southern China and northern Vietnam, Journal of Acquired Immune Deficiency Syndromes, 2005, 38(2):228-235; Nguyen TH, Nguyen TL and Trinh QH, 2004, op. cit. (see reference 3); and Vu MQ et al., 2000, op. cit. (see reference 3).

14. Go VF et al., Intra-couple communication dynamics of HIV risk behavior among injecting drug users and their sexual partners in northern Vietnam, Drug and Alcohol Dependence, 2006, 84(1):69-76.

15. Hammett TM et al., 2005, op. cit. (see reference 13); Joint United Nations Programme on HIV/AIDS (UNAIDS) and the World Health Organization (WHO), AIDS Epidemic Update, December 2004, Geneva: UNAIDS, 2004; and United Nations Development Programme (UNDP), Thailand's Response to HIV/AIDS: Progress and Challenges, Bangkok: UNDP, 2004.

16. Nguyen AT et al., Intravenous drug use among street-based sex workers, Sexually Transmitted Diseases, 2004, 31(1):15-19; Nguyen TTT et al., HIV infection and risk factors among female sex workers in southern Vietnam, AIDS, 1998, 12(4):425-432; Trung NT et al., Drug use among female sex workers in Hanoi, Vietnam, Addiction, 2005, 100(5): 619-625; and UNAIDS and WHO, AIDS Epidemic Update, December 2005, Geneva: UNAIDS, 2005.

17. Belanger D and Khuat TH, Marriage and the family in urban north Vietnam, 1965-1993, Journal of Population, 1996, 2(1):83-112; and Goodkind D, State agendas, local sentiments: Vietnamese wedding practices amidst socialist transformations, Social Forces, 1996, 75(2):717-742.

18. Taylor P, Fragments of the Present: Searching for Modernity in Vietnam's South, Honolulu, HI, USA: University of Hawaii Press, 2001; and Jamieson NL, Understanding Vietnam, Berkeley, CA, USA: University of California Press, 1993.

19. Hiebert M, Vietnam's dichotomy, Far Eastern Economic Review, 1992, 155(41):46-48.

20. Hiebert M, Chasing the Tigers: A Portrait of the New Vietnam, New York: Kodansha International, 1996; Nguyen TH and Wolffers I, HIV infection in Vietnam, Lancet, 1994, 343(8894):410; and Rekart ML, Sex in the city: sexual behaviour, societal change, and STDs in Saigon, Sexually Transmitted Infections, 2002, 78(Suppl.1):i47-i54.

21. Hiebert M, 1992, op. cit. (see reference 19); and Taylor P, 2001, op. cit. (see reference 18).

22. Dollar D and Litvack J, Macroeconomic reform and poverty reduction in Vietnam, in: Dollar D, Glewwe P and Litvack J, eds., Household Welfare and Vietnam's Transition, Washington, DC: World Bank, 1998.

23. Hiebert M, 1992, op. cit. (see reference 19); and Taylor P, 2001, op. cit. (see reference 18).

24. Population Division of the Department of Economic and Social Affairs of the United Nations Secretariat, World Population Prospects: The 2004 Revision, Population Database, 2004, <http://esa.un.org/unpp>, accessed Aug. 25, 2005.

25. Knodel J, Napaporn H and Sittitrai W, Family size and the educa- tion of children in the context of rapid fertility decline, Population and Development Review, 1990, 16(1):31-62.

26. Author tabulations of data from Vietnam Ministry of Health et al., 2005, op. cit. (see reference 6).

27. Committee for Population, Family and Children, and ORC Macro, Vietnam Demographic and Health Survey 2002, Calverton, MD, USA: Committee for Population, Family, and Children, and ORC Macro, 2003; and Poverty Working Group, Vietnam Development Report 2000: Attacking Poverty, Washington, DC: World Bank, 1999.

28. Linh CL et al., A pilot of audio computer-assisted self-interview for youth reproductive health research in Vietnam, Journal of Adolescent Health, 2006, 38(6):740-747.

29. Hammett TM et al., Development and implementation of a crossborder HIV prevention intervention for injection drug users in Ning Ming Country (Guangxi Province), China and Lang Son Province, Vietnam, International Journal of Drug Policy, 2003, 14(5-6):389-398.

30. Morris M et al., Bridge populations in the spread of HIV/AIDS in Thailand, AIDS, 1996, 10(11):1265-1272.

\section{RESUMEN}

Contexto: Se considera que la actividad sexual antes del matrimonio se encuentra en ascenso en Vietnam. Sin embargo, hay pocas pruebas que documenten este aumento y no se sabe si los niveles de actividad sexual son diferentes entre las regiones del norte y el sur de Vietnam, y si esta actividad sexual ocurre fundamentalmente con el futuro cónyuge.

Métodos: Las encuestas realizadas en el norte de Vietnam (Delta del río Rojo) y en el sur de ese país (la ciudad Ho Chi Minh y sus alrededores) en 2003-2004, a personas casadas durante uno de los tres períodos históricos de Vietnam (1963-1971, 1977-1985 o 1992-2000) fueron utilizadas para evaluar las tendencias y diferencias regionales de las prevalencias y el contexto de la actividad sexual antes del matrimonio.

Resultados: La prevalencia de las relaciones sexuales antes del matrimonio aumentó notablemente entre los cohortes de 1963-1971 y 1992-2000 en el norte (de 6\% a 31\% entre hombres y de $0.5 \%$ a $12 \%$ entre mujeres), pero más modestamente en el sur (de $24 \%$ a $31 \%$ entre hombres y de $3 \%$ a $8 \%$ entre mujeres). Relativamente pocos hombres tenían relaciones sexuales premaritales con alguien que no fuera su futura esposa (3-23\%). La proporción del aumento de la prevalencia de la actividad sexual antes del matrimonio que se debió a las relaciones sexuales con la futura esposa exclusivamente fue más elevada en el norte (42\%) que en el sur (25\%).

Conclusiones: Estos resultados sugieren que la actividad sexual antes del matrimonio es cada vez más común en Vietnam, aunque aún no está ampliamente difundida. Es necesario disponer de mejor información sobre las redes de actividad sexual de los hombres en la población en general y sobre sus contactos con los grupos de alto riesgo (por ejemplo, con las trabajadoras sexuales comerciales) para determinar el nivel de riesgo que existe de propagar la infección del VIH/SIDA a la población en general.

\section{RÉSUMÉ}

Contexte: L'activité sexuelle antérieure au mariage semble en hausse au Vietnam. L'accroissement n'est cependant guère documenté. On ne sait du reste pas si la prévalence de cette activité diffère entre le nord et le sud du pays, pas plus que si le phé- 
nomène concerne principalement les futurs époux.

Méthodes: Des enquêtes menées dans le nord (delta du fleuve Rouge) et dans le sud du pays (Ho Chi Minh City et environs) en 2003-2004 auprès de personnes mariées durant l'une de trois périodes de l'histoire vietnamienne (1963-1971, 1977-1985 ou 1992-2000) servent à évaluer les tendances et les différences régionales de la prévalence et du contexte des relations sexuelles antérieures au mariage.

Résultats: Dans les deux échantillons régionaux, 31\% des hommes mariés pendant la période de 1992 à 2000 ont déclaré avoir eu des rapports sexuels avant le mariage. La proportion est beaucoup plus faible parmi les femmes ( $8 \%$ dans le sud et $12 \%$ dans le nord). La prévalence de l'activité sexuelle antérieure au mariage augmente nettement d'une cohorte à l'autre dans le nord, mais modérément dans le sud. Relativement peu d'hommes avaient eu des rapports avec une partenaire autre que leur future épouse (3-23\%). La proportion de la hausse de prévalence attribuable aux rapports exclusifs entre futurs époux était supérieure dans le nord (42\%, par rapport à 25\% dans le sud).

Conclusions: Ces résultats laissent entendre que les relations sexuelles antérieures au mariage deviennent plus courantes au Vietnam mais ne sont pas encore généralisées. Une meilleure information sur les réseaux sexuels des hommes de la population générale et de leurs contacts avec les groupes à hauts risques (les travailleuses du sexe, etc.) est nécessaire à l'évaluation du risque de propagation du VIH/sida dans la population générale.

\section{Acknowledgments}

This research was supported by grants from the National Institutes of Health's Fogarty International Center and a postdoctoral training fellowship from the National Institute of Child Health and Human Development, all awarded to the University of Michigan, and by the Population Council fellowship fund. We thank Barbara Mensch for her comments on this paper.

Author contact: sghuman@popcouncil.org 